\title{
A re-evaluation of tenses in isizulu
}

\begin{abstract}
Author:
Hermanus C. Groenewald ${ }^{1}$

Affiliation:

${ }^{1}$ Department of African Languages, University of Johannesburg, South Africa
\end{abstract}

\section{Correspondence to:}

Hermanus Groenewald

Email:

hcgroenewald@uj.ac.za

Postal address:

PO Box 524, Auckland Park

2006, South Africa

\section{Dates:}

Received: 26 Oct. 2012

Accepted: 15 July 2013

Published: 13 Aug. 2014

How to cite this article: Groenewald, H.C., 2014,

'A re-evaluation of tenses in isiZulu', Literator 35(1),

Art. \#1062, 8 pages. http:// dx.doi.org/10.4102/lit.

v35i1.1062

\section{Copyright:}

(C) 2014. The Authors. Licensee: AOSIS

OpenJournals. This work is licensed under the

Creative Commons

Attribution License.

Read online:

Scan this $Q R$ code with your smart phone or mobile device to read online.
The methodology of this article involved an examination of theoretical and empirical data so as to ascertain what the defining grammatical and semantic nature of tenses in isiZulu are with the ultimate goal of presenting an alternative view of these tenses. The article examined selected studies on the theory of tense in general as well as work done specifically on tenses in isiZulu. The most prolific scholar in South Africa writing on tenses in isiZulu is L.C. Posthumus. His studies, particularly those of 1990 and 2008, were examined so as to highlight problems with regard to suppositions and terminology. The conclusion of this discussion was that the basis on which a distinction is made between the so-called absolute and so-called relative tenses in isiZulu is contentious. Examples of tensed clauses in all the tenses in isiZulu taken from the empirical data were then examined in order to gain a sense of the defining temporal information communicated by these clauses. Having discussed these examples alternative terms for some tenses were suggested. The empirical data that guided the discussion and provided examples of tensed clauses are drawn from selected narrative texts. The findings with regard to terminology and the temporal information of tenses in isiZulu were then summarised.

'n Herwaardering van tydvorme in isiZulu. Die werkwyse van hierdie artikel het die nagaan van teoretiese en empiriese data in 'n soeke na die onderskeidende grammatiese en semantiese aard van die tydvorme in isiZulu behels. Die doel daarvan was om 'n alternatiewe siening van hierdie tydvorme aan te bied. Gekose studies oor die teorie van tydaanduiding in die algemeen asook studies oor die tydvorme van isiZulu in die besonder is nagegaan. Die werk van L.C. Posthumus - die produktiefste skrywer in Suid-Afrika oor isiZulu-tydvorme - is bespreek en problematiese uitgangspunte en terme is uitgelig. Veral sy artikels van 1990 en 2008 is van belang. Die gevolgtrekking is gemaak dat die uitgangspunt waarvolgens onderskeid tussen die sogenaamde absolute en relatiewe tydvorme in isiZulu getref word, aanvegbaar is. Vervolgens word voorbeelde uit die empiriese data van tydaanduidende werkwoordstukke vir al die tye in isiZulu ondersoek met die doel om 'n begrip te kry van die onderskeidende temporale inligting wat hierdie tydaanduidende werkwoordstukke kenmerk sodat alternatiewe terme vir sekere tydvorme voorgestel kon word. Die empiriese data het uit gekose narratiewe tekste bestaan. Die bevindings oor terme en temporale inligting oor die tydvorme in isiZulu is laastens opgesom.

\section{Introduction}

The goal of this article is to present an alternative view of isiZulu tenses after ascertaining what the defining grammatical and semantic nature of these tenses are. This will be done against the background of selected theoretical views on tense in general as well as specific studies on the tenses in isiZulu. It will be followed by an examination of empirical data, namely tensed clauses as they appear in a number of narrative texts, with the view to gain a sense of precisely how the different tenses are used grammatically and semantically. Having examined the studies on tense as well as examples of tensed clauses in narrative texts, the aim is ultimately to suggest alternative nomenclature and an alternative classification of tenses in isiZulu. Since the corpus of tensed clauses is taken from only three narrative texts - two novels and a collection of short stories by different authors - it can be argued that the corpus is too small to provide dependable results. It must be noted that this is a qualitative study representing a writer's particular view of isiZulu tenses. This article does not endeavour to ascertain the frequency of occurrence of the different tenses from large databases. If one takes into account that the selected narrative texts have a combined total of 598 pages and that it is possible to encounter between 30 and 50 tensed clauses on a page (depending on the length of the page), it is reasonable to accept that these texts provide a good sample of empirical data from which credible deductions can be made.

Following Comrie (1985), Smith (2008:231) describes tense as follows: '[...] tense is a morpheme that expresses temporal information, a verbal inflection or auxiliary. The tense morpheme is obligatory, part of the grammatical "spine" of a sentence'. In this publication Smith discusses three 
types of languages in the matter of tense: tensed languages, mixed temporal languages, and tenseless languages. In tensed languages, according to Smith (2008:246) '[...] every sentence has direct information about temporal location'. Mixed temporal languages, according to Smith (2008): '[...] may have grammatical temporal forms, but they are optional and do not appear in every clause.' It can be said that isiZulu is a mixed temporal language in which many of the clauses are tensed whilst others do not display direct temporal information. The most obvious example of the fact that some verbs in isiZulu do not display tense morphemes is that, of the seven moods in isiZulu, only three take tense morphemes.

\section{The tenses of isizulu}

Virtually all isiZulu grammarians describe the tenses of isiZulu. Doke's ([1927] 1988:162) view gives an idea of the general nature and range of tenses in isiZulu:

The isiZulu tense division according to time is not so clear and precise as that of many other African languages, nevertheless in the main, the general African division holds for isiZulu, viz:

1. remote past

2. immediate past

3. present

4. immediate future

5. remote future.

A study of tenses in isiZulu has been undertaken by a few scholars, notably by Posthumus (1982, 1984, 1988, 1990, 2001, 2006, 2008). Using the distinction between absolute and relative tenses as described by Comrie (1985:36, 56), Posthumus published his analyses in a number of articles on the absolute tenses (reference will be made to 1990) and the relative tenses (reference will be made to 2008). Tenses in isiZulu are recognised through morphemic interventions in the clause, whether these interventions are prefixal, infixal, suffixal, or a combination of these. Grammatically, the socalled absolute tenses are recognised by the use of a prefix, infix, or a suffix. Semantically, they have been distinguished on the grounds of two reference points: when the event occurs (past or non-past), which is referred to as event time (ET), and when the speaker refers to the event, which is referred to as speech time (ST) or in Posthumus's (1990:23) terminology, coding time (CT). In addition, tenses can be described in terms of reference time (RT); this reference point is, in Posthumus's (2008:75) discussion, particularly relevant to the so-called relative tenses. Grammatically, the relative tenses are marked by the auxiliary verb -be. Posthumus (1990:23) distinguishes the following absolute tenses in isiZulu - the examples given in Table 1 are the present author's.

TABLE 1: Absolute tenses in isiZulu.

\begin{tabular}{lll}
\hline Remote past & Past & Present \\
\hline Ngabhala. & 1. Ngibhalile. & 1. Ngiyabhala. \\
$\begin{array}{l}\text { Angibhalanga. (NEG) } \\
\text { [I wrote./I didn't write.] }\end{array}$ & $\begin{array}{l}\text { 2. Ngibhale +ARG. } \\
\text { Angibhalanga. (NEG) } \\
\text { [I wrote./I didn't } \\
\text { write.] }\end{array}$ & $\begin{array}{l}\text { 2. Ngibhala +ARG. } \\
\text { [I write./I I don't } \\
\text { write.] }\end{array}$ \\
\hline
\end{tabular}

Source: Posthumus, L.C., 1990, 'Time reference in Zulu', South African Journal of African Languages 10(1), 22-28.
The morphemes through which the clauses are tensed are underlined; full explanations of these clauses will be provided insection four and section five. Posthumus, likemany linguists, does not recognise a future tense. Posthumus (2008:77) recognises four basic relative tenses, each with four variants (ibid:77).

\section{Premises}

The author of this article is inclined toward the principle in 'functional grammar' that states that language functions as a system of human communication. This is in contrast to the principle that views 'language as an abstract set of generalized rules detached from any particular context of use' (Thompson 2004:1). Context of use, or discourse, is an important issue in this article, not only to situate the examples clearly, but also to demonstrate how these examples can shed light on the inherent semantic nature and thus the uses of tenses in isiZulu. With regard to discourse Kashina (2005:22) says the following: 'Discourse (or text) is the most inclusive unit and reflects the realities of oral and written communication'.

The question that may arise about the particular discourse chosen, namely that of literary language, is whether literary language is in fact a reliable indicator of the general use of the tenses of isiZulu. The premise for this article regarding literary language is that although written narrative discourse can be regarded as 'heightened' language use, it resembles natural oral discourse in the sense that writers, like speakers, cannot invent grammar regardless. Although writers and speakers make use of ungrammatical language use for special purposes, the range of 'mistakes' is relatively well known to readers and listeners and these 'mistakes' are not regarded as mistakes but rather as 'literary language'. Thus I regard the use of tenses in narrative discourse as described in this article as a barometer of well-formed discourse. Literary language use may have some implications for the use of tenses, but literary language use cannot disrupt the system of tenses without creating considerable confusion in the reader. The writer cannot afford to create confusion if he or she wants to communicate a message - and this is what literature is about - to communicate ideas and not to be exhibitionist about language use in the first place.

The use of the word 'absolute' in the term 'absolute tense(s)' as used by Posthumus is problematic, intrinsically, as well as in the light of how tenses have been used by writers in narrative discourse. Referring to intrinsic meaning, 'absolute' according to Grandison et al. (1990), has the following meanings:

1. complete, perfect

2. free from restrictions or exceptions

3. undoubted, certain

4. not dependent on or relative to anything else

5. pure, unmixed.

Presumably meaning number four was chosen to describe the absolute tenses. The description 'absolute' is incompatible 
with the notion of deixis. Posthumus (1990:23) maintains in his deliberations on tense that tense is a deictic entity; tense is thus interpreted according to relations and not on absolute grounds. Posthumus (1990:23) says 'Deictic time reference is above all grammaticalised in the tense forms. ${ }^{\prime 1}$ In the deictic sense then all tenses are 'relative'; they are all interpreted according to the vantage point of the speaker or hearer. The analysis of the tenses will hopefully show that there is no need, in the case of isiZulu, from a pragmatic point of view, to make the distinction between absolute and relative tenses based on grammatical form, because there are often no clear, 'absolute' differences in use between certain tenses, as the examples will show. Comrie (1985) himself writes as follows about the problem of the term 'absolute tense':

The term is misleading because, since the only way of locating a situation in time is relative to some other already established time point; the present moment is in principle just one of an infinite number of such time points that could be chosen as reference point, although it does play a major role in the definition of tense systems across the languages of the world. (p. 36)

A further difficulty is the principle according to which the relative tenses have been established. According to Posthumus (2008:75) the primary reference point is the 'morphological structure of the (deficient) auxiliary verb with -be [...]'. For example in the clause Sasigijima [We ran], a contraction of sabe + sigijima, the introductory (auxiliary) part [sabe], which marks the temporal reference to the past, is the 'primary reference point', according to Posthumus. In other words, this reference point is in fact identified on the grounds of an (absolute) tense reference (in conjunction with $-b e)$ as it contains a remote past tense morpheme $(-a)$. The question then arises: how does this differ in principle from a so-called absolute tense indicating a past which is also marked by a remote past tense morpheme $(-a)$ as for instance in Sagijima. If, on the other hand, Posthumus's notion of 'the primary reference point' refers to the the auxiliary verb -be, the problem is still not solved since -be as grammatical item is not inherently indicative of or warranted by reference time (RT).

In this study, then, the distinction between absolute and relative tenses based on the absence or presence of -be will eventually be discarded. Examples of the so-called absolute tenses will be now discussed to show how these have been used in narrative texts.

\section{The basic tenses The remote past tense}

IsiZulu speakers are well-acquainted with the phrase Laduma!, which is in the so-called remote past, to indicate that the soccer ball has struck the net, in other words that a goal has been scored. The clause literally means 'it has thundered' and describes how the ball has 'thundered' against the net. This phrase is clearly never used in soccer commentary to indicate

1.It must be noted here that since isizulu tense forms are formed mostly by agglutination and not by grammaticalisation, Posthumus has used the term grammaticalisation wrongly in this context. Lehmann (2002:7) defines grammaticalisation as 'a process wrongly in this context. Lehmann (2002:7) defines
leading from lexemes to grammatical formatives'. an event that occurred in the remote past. When an isiZulu warrior received a fatal wound in battle or was faced with a life-threatening situation he may shout Ngafa! [I am dead!]. Again, this expression, in the remote past tense, refers to an event that occurred seconds before ST. One more example from oral art: the verbs in the well-known slogan or song Wathint' abafazi wathint' imbokodo [You strike a woman, you strike a rock], originally sung by the women who marched to the Union Buildings in 1956 to protest against the pass laws, are also grammatically in the so-called remote past tense and yet the women are not referring to an event in the remote past. In fact, the meaning conveyed indicates a (conditional) presence: if you strike a woman, you (will) get hurt. If these examples are somewhat exceptional (although by no means ungrammatical), other examples from narrative texts will corroborate the true nature of the so-called remote past tense. In the novel Kuxolelwa abanjani? (see Sibiya 2002:1) the main character Shumi Gumede has just lost his job, and leaving his work place, he walks to his car; the narration continues as follows: Kwaba wukungena nje emotweni kumfo kaGumede, wabhaklaza isicabha, wazitshinga esihlalweni, wagobodisa phezu kwesitelingi, izandla wazibethela esipundu, wakhala, wakhala, wakhala. [Then Gumede got into his car, he banged the door, he strapped himself in, he placed his head on the steering wheel, he placed his hands over his head, he cried, and cried, and cried] (Sibiya 2002:1). ${ }^{2}$

Explanation: Only one example in this paragraph will be explained grammatically:

\begin{tabular}{|c|c|c|}
\hline$w a \quad(<u$ & + & bhaklaza \\
\hline $\begin{array}{l}\text { (SM CL 1a+ } \\
\text { He }\end{array}$ & $a$-past MOR) & $\begin{array}{l}\text { V STEM } \\
\text { bang }\end{array}$ \\
\hline
\end{tabular}

The remote past, is thus formalised through fusion of the subject morpheme (SM) with a formative $-a$. In the context of the narration, the verbs, all in the so-called remote past tense, clearly do not refer to events that occurred in the remote past. The remote past can of course be a vehicle to refer to events in the remote and relatively remote past when it is necessary to indicate a remote time frame: 'Inkosazane yakulo muzi uNtokozo yamaJoko waqanjwa yimina' [The daughter of this house Ntokozo Joko was named by me] (Makhambeni 2006:2).

In the texts consulted, examples of the so-called remote past indicating recent past actions (and in one case an event in the present) outnumber remote events. An example indicating an event enduring in the present is as follows: 'Hawu, wathula kangaka Fuze. Ucabanga indaba kaMpiyakhe yini?' [My word, you are so quiet Fuze. Are you thinking about the matter concerning Mpiyakhe?] (Makhambeni 2006:25).

The so-called remote past evidently refers to events in the past, whether recent or remote. This is in accordance with the finding of De Clercq (1961:11), who found that 'Die a-verlede

2.Literal translations of examples are avoided because such translations often may make no sense. A dynamic equivalent translation is thus preferred. However, the original punctuation is retained in translation so that the English translation can in some way be compared to the isizulu phrases. 
tyd is ' $n$ suiwer verlede tyd wat die logiese tydstip, naamlik van verre of nabye verlede, kan aandui.' [The a-past tense is a pure past tense that indicates the logical point in time of remote or recent past.] See also Sithole (2003:161), who comes to the same conclusion. The primary semantic function of this tense is to mark events as 'seminal'. The so-called remote past tense highlights events in narration (whether oral or written). In terms of theories of event structure, this tense indicates activities, accomplishments and achievements, rarely states, with the specific semantic value [+seminal]. I thus suggest that this tense be named the narrative tense, or more neutrally the $a$-past tense, as some scholars have indeed done, see De Clercq (1961) and Sithole (2003), since it is always constructed with subject marker plus formative $-a$. According to Posthumus the $a$-past tense has the negative (see Table 1) resembling the negative of the past tense. But it also has its own negations, one of which is to prefix a negating morpheme (k)a-: 'Kwenzenjani mfo kaGumede, kawaze waya ekhaya, unkosikazi ukuxoshile yini?' [What's wrong Gumede, you haven't even gone home (yet), has your wife thrown you out?].

The negative of the $a$-past tense is not a common occurrence in discourse, for obvious reasons: the writer has greater need for seminally expressing an event than negating it.

\section{The past tense}

According to most grammarians the past tense is characterised by two suffixes, each appropriate to a syntactic environment: the short form $(-e)$ terminates the verb stem when the clause is followed by an adverb/ adverbial phrase, whilst the long form (-ile) is usually, but not exclusively, found in clause terminal position. There are, however, contexts where the short form can occur in a clause terminating the sentence whilst the long form can occur in non-terminating clauses (see examples below). If the $a$-past tense according to Posthumus's (1990:23) diagram refers to remote past events then the past tense logically refers to recent past events, but, as his diagram suggests, there is an overlap between these two forms; in fact they can co-occur in adjacent phrases and can refer to the same time, as the following example shows: 'Nafunda ndawonye. Okungahlukene ukuthi nikhule ndawonye nabo (abantu abamnyama).' [You studied together. What is (thus) not different is that you grew up together with them (black people).] (Makhambeni 2006:49).

Like the $a$-past tense, the past tense can refer to recent past events (Sibiya 2002:8): 'Ya ndoda, ngize kuwe'. NguMahlangu lona obhavumula ngolaka, [...] ['Yes $\mathrm{Sir}^{3}$, I have come to you.' This is Mahlangu shouting in anger, [...]].

Unlike the $a$-past tense, the past tense is not used in any great measure to narrate. What then are its distinguishing features in narrative discourse? In the first place it may express events that do not feature as seminal events, especially in the short form. Secondly, it is an expression of the stative;

3.Ndoda means 'married man'; 'Sir' is possibly the closest equivalent in English. thus, whenever a state needs to be expressed, the 'past tense' suffixes, either $-e$ or $-i l e$, can be used, as in the following example:

[...] Umpintsheke kanjani namuhla?

Khona ngimpintshekile, njengoba wazi nawe ukuthi sesizobhala. [...]

[[...] How pressed/ busy are you today?]

[Well, I am pressed/ busy, as you know we will be writing. [...]] (Makhambeni 2006:19)

\section{Explanation:}

$\begin{array}{lll}\text { U } & \text { mpintshek } & e \\ \text { SM 2p.s. } & \text { V ROOT } & \text { V SUFF (short form) } \\ \text { You } & \text { busy } & \text { (stative) } \\ \text { Are you busy? } & & \\ \text { Ngi } & \text { mpintshek } & \text { ile } \\ \text { SM 1p.s. } & \text { V ROOT } & \text { V SUFF (long form) } \\ \text { I } & \text { busy } & \text { (stative) }\end{array}$

I am busy.

In the stative form the short form can occur in a clause in sentence terminating position. When former President Thabo Mbeki addressed the crowd at the Union Buildings after the second national election (1998) he asked them 'Nijabule?' [Are you happy?] The stative can be expressed for past, present, or future; thus the stative is not a tense. Thirdly, past tense verbs serve to indicate perfectivity or completion, often in conjunction with the auxiliary for completion, -se. The following examples illustrate completion:

Ngaleso sikhathi usewutholile umsebenzi kwaSitshodo. [At that time he had already found work at Sitshodo's place.] (Makhambeni 2006:5)

Afikelewe ngukuzenyanya u-Alex uma ecabanga ukuthi usegqigqe ngemuva kukaThulisile izinyanga eziyisishiyagalolunye zonke emqomisa kodwa ahluleke. [Alex felt disgusted as he thought that he had already chased after Thulisile for nine months courting her without success] (Makhambeni 2006:78)

What Posthumus (1990) calls the past tense, Taljaard and Bosch (1998:55), Sithole (2003:150), and some other scholars in fact call the perfect, reserving the term 'past tense' for the a-past tense; Taljaard and Bosch (1998) describe the perfect as follows:

The perfect is an aspect expressing completed action. Aspect as such does not locate time, i.e. it does not necessarily indicate when an action takes place; it indicates how an action is performed within the setting of time. (p. 55)

The aspect of perfectivity is often expressed by means of so-called relative tenses. The very fact that the past tense or perfect (henceforth: past tense) can co-occur in the relative tenses is proof that the past tense can be used to indicate something other than tense, since one clause cannot host different tenses. The following example shows the cooccurrence of the so-called recent past relative tense and the 'past tense' (functioning as the aspect of perfectivity): 'Wena Themba ubuthembise ukuza enkonzweni yakusihlwa izolo kubuye kwenzenjani?' [Themba you did promise yesterday to come to the evening service, what is going on?] (Makhambeni 2006:103). 
Fourthly, the past tense functions to confirm that an event has indeed taken place, especially through the use of the long form. The background to the following example is as follows: In the novel 'Kuxolelwa abanjani' Shumi has come to meet his former girlfriend; his conscience troubles him and he makes an attempt to excuse himself. The girlfriend, however, emphasises that she has made a booking: 'Ngibhukile lapha ehhotela.' [I have (actually) booked in here at the hotel.] (Sibiya 2002:91).

Here -ile confirms the event. (See the discussion for its parallel form, the long form of the present tense, below.) The short form of the past tense (-e) clearly has a dual function: it expresses past time (not necessarily recent, but mostly so) and it expresses stative and perfect events. The recent past thus expresses a range of events: states, activities, and accomplishments.

Both the short and long forms of the past tense share the same negative, namely by means of negating prefix and suffix. In aspectual mode (namely to confirm) the suffixes -ile and $-e$ are retained in the negative. Examples:

Neutral negative indicating past event: Futhi ngabe kungcono nokuthi nalo Mevana wakhona akayenzanga lutho insizwa yami uVusi lapha epulazini [...] [Furthermore it is perhaps better that this Mevana of yours did not do anything to my boy Vusi here on the farm [...]] (Makhambeni 2006:45).

Negative retaining long form to confirm: '[...] Angizile ukuzokulwa namuntu $[\ldots]\left[[\ldots]^{\prime} \text { I have not come to fight with anyone }[\ldots]\right]^{\prime}$ (Makhambeni 2006:47).

Negative retaining short form to confirm: '[...] kubonakala nje ukuthi kayifune muntu ozohlala eduze kwayo' [[...] it is clear that she did not want anyone to sit close to her.] (Sibiya 2001:13). In addition: Makhambeni (2006:44): 'Ingane ayenze lutho. Akuyona eyaziletha lapha emhlabeni!' [The child hasn't done anything. It did not bring itself into the world!]

Explanation: Only one example will be explained:

$\begin{array}{lllll}a & k a & y & \text { enz } & \text { anga } \\ \text { NEG PREF } & \text { NEGSMCL1 } & \text { OBJ MCL9 } & \text { V ROOT } & \text { NEGSUFF } \\ \text { Not } & \text { he } & \text { him } & \text { do } & \end{array}$

He did not do.

As can be seen in the two examples above, the negatives retaining suffix - $e$ appear in association with nouns used in the generic form (without initial vowel, e.g.: (u)muntu [black person] of which the translation is often 'any [plus basic meaning of the particular noun]' and the intention of the speaker is one of confirmation.

\section{The present tense}

This tense refers to events that correspond to ST. It has parallels with the past tense in that it has two grammatical forms which correspond to syntactic environments as described for the past tense. The long form (marked by infix $-y a-)$ serves to confirm the event, whilst the short form allows the focus to move to an argument in the sentence, or, as in the following example, to a subordinate clause (Sibiya 2002): [...] 'Lethiwe, ngiyakuthanda, ngikuthandela ukuba sakhe umuzi nawe.' [...] (p. 7) [[...] Lethiwe, I love you, I love you so that we can have our own family. [...]]

(The stem -thandela contains the applicative suffix (-thand$+-e l-+-a$ ) indicating purpose, beneficiary or other semantic values.)

As in the case of the long form of the past, the tense status of the long form of the present tense needs to be examined. The long form of the present is compulsory in clause final position, whilst semantically it serves to highlight or emphasise the event. If the tense status of the long form of the past tense is questionable then there are equal grounds to question the tense status of the so-called long form of the present tense. On equal grounds (as described for the long form of the past tense above), the morpheme $-y a-$ should be seen as an aspect indicating significance or weight. If $-y a-$ is the formalisation of present tense, as some isiZulu grammarians imply, the short form must be a formalisation of some other function, which, apparently, is not the case, as no isiZulu grammar ascribes a special semantic function to the so-called short form. The short form should, in my view, be regarded as the norm for the present tense, whilst the long form should be regarded as an aspect indicating weight (associated with present tense). On -ya-Sithole (2003) comments as follows:

This morpheme does not directly contribute to any difference in the meaning of the Present Tense with regard to its interpretation of time. However, [...] the presence or absence of [-ya-] may give rise to a certain emphasis on the action or event designated by the verb. It is however, clear that the distinction between these two forms of the Present Tense is primarily syntactic in nature, and secondary, only with regard to the semantic feature of emphasis and not to any feature which is exclusively related to time. (pp. 143-144)

\section{The future tense}

As indicated by Posthumus (1990:23), isiZulu does not have a morpheme exclusively indicative of the future; even so, many isiZulu grammarians speak of the 'future tense' (Poulos \& Msimang 1998:263; Taljaard \& Bosch 1998:61; Van Eeden 1956:274). Speakers often distinguish between a definite and an indefinite future, as the following example illustrates: [...] 'Ngiyobuya ngize ngapha ngizosho ukuthi sihambe kanjani.' [I will (at some time) come back here and will (surely) say how we faired] (Makhambeni 2006:31).

The primary semantic function of the aspects zo or yo is to indicate (definite or indefinite) immanence, translated as 'coming to [verb]/going to [verb]'. The clearest proof that $z o$ or yo do not primarily mark tense is the fact that they can occur in a tenseless mood (such as the infinitive) and that they can occur with other tenses. 


\section{The relative tenses}

Comrie (1985:56) sees the relative tense as a tense 'where the reference point for the location of a situation is some point in time given by the context, not necessarily the present moment.' The difficulty (for the relative tenses in isiZulu) arises when he gives examples of these reference points, as follows:

[...] there are (in general distinct) adverbials which locate a situation relative to some reference point given by the context, such as on the same day, on the day before, on the next day; in our terminology, these are all instances of relative time reference. (Comrie 1985:56)

The problem is not that similar types of relativeness do not occur in isiZulu; they do occur. The difficulty, firstly, is that the so-called relative tenses in isiZulu - that is to say, tenses constructed with the auxiliary verb - be - do not need a reference point given by the context in order to exist; secondly, some of the examples given by Comrie are not always compatible with some 'relative tenses' in isiZulu. Examples such as the following are less acceptable in isiZulu discourse: Ngalelo langa wayethenga imoto. [On that day she or he bought a car.] Ngosuku olungaphambi kwalolo wayethenga imoto. [On the day before that he or she bought a car.]

Thirdly, some isiZulu equivalents of the English adverbials given as examples by Comrie (1985:56) do not require a relative tense: Mhla efika uzothenga imoto. [On the day he or she arrives he or she will buy a car].

The clause efika is a present tense form of the participle mood (also referred to as the situative mood); this mood is compulsory and the present tense form common after the time conjunctive mhla [on the day]. Fourthly, Comrie (1985:56) recognises relative tenses on contextual and not on grammatical grounds; the socalled relative tenses in isiZulu have clearly been identified on grammatical grounds, that is, the fact that they are formed by means of the auxiliary verb - be.

\section{The A-past compound tense}

It must be noted, as Posthumus (2008:69) has shown, that what he calls relative tenses have been called past continuous tenses, compound tenses, and some other names by scholars. Having reviewed the nature of these tenses and their naming by other scholars, Posthumus prefers to name the relative tenses according to two reference points: the tense in which the auxiliary verb occurs and the tense in which the complementary verb occurs. For instance, the following example is called 'a relative tense with reference time long before coding time and event time coinciding with reference time': Ngangisebenza. [I was working or I worked] (Posthumus 2008:77).

Since this example contains an $a$-past tense (remote past in Posthumus's [2008] terminology) in the auxiliary phrase ( $n g a$ $+b e$ ), Posthumus will name the tense accordingly ('reference time long before coding time'). His naming of these tenses, of which there can be at least 16 variants if one takes the auxiliary phrase as well as the complement into consideration, is more than providing terminology: it amounts to a description or a definition. This system is quite cumbersome to use. Some scholars refer to these tense forms as 'compound tenses', since all these forms are made up of two verbs: the auxiliary verb and main verb (or: complement). Posthumus (ibid:73) rejects the term 'compound tense' on the grounds that it 'implies that such verbal forms comprise a combination of two (or more) tenses; which is not the case and this term is thus equally unfit'. The term 'compound' does not necessarily refer to the tense aspect; it can refer to the fact that the clause is a compound of two verbs: an auxiliary and a main verb stem. If the term 'compound' is an issue - note that in a certain sense the future is also a compound tense (Sithole 2003:167) - one could call these tenses - be tenses. Despite the fact that the auxiliary verb stem $(-b e)$ can be omitted in contracted forms of these tenses, its underlying meaning (namely of referring to a situation, or simply put, of 'being' in a certain situation) is often operative. This does not mean that isiZulu writers express this situation explicitly, for instance with reference to a time word or phrase. For example, Sibiya's (2002:1) novel Kuxolelwa abanjani? commences as follows without reference to a specific time: Kwakugobhoza imvula yezinyembezi, ekhanda kuduma izinhlonono ezazenza uShumi angabezwa nabantu ababembingelela ngenkathi egxawuzela eya emotweni yakhe. [A torrent of tears came down, in his head a tumultuous noise resounded causing (= which caused) Shumi not to hear the people who greeted him as he went to his car].

\section{One of the verbs in the example above will be explained:}

\begin{tabular}{llll} 
Kwabe (auxiliary verb) & + & kugobhoza $($ main verb) & \multicolumn{3}{l}{ Kwakugobhoza. } \\
Kwa $(<k u+a)$ & be & $k u$ & gobhoza \\
A-past SM CL 15 & AUX & SM CL 15 & V STEM \\
It & be & it & flow
\end{tabular}

There flowed.

The situation which serves as context for this paragraph is Shumi's retrenchment. This situating of the discourse does not mean that the narrator has to continue in this tense. The example given above is followed immediately by the example given for the $a$-past tense earlier; thus the events referred to in this paragraph do not refer to a remote past time. In the context of the story these verbs (those in the 'relative tense with reference time long before coding time and event time coinciding with reference time' as well as those in the $a$-past tense discussed earlier) refer to an immediate past. Therefore, in line with the suggestion made earlier that the so-called remote past be called the $a$-past tense, I suggest that the tense under discussion be called the $a$-past compound tense, as it serves very much the same function as the $a$-past tense. In narrative discourse there seems to be little difference between the $a$-past tense and the $a$-past compound tense; they occur in the same context. In the following example the a-past compound tense follows the a-past tense: Kwamcacela ukuthi amashwa ayemqondile. [It became clear to him that misfortune was meant for him.] (Sibiya 2002:3).

A writer may switch to the $a$-past compound tense because of its versatility: both the auxiliary part as well as the complement can conjugate relatively extensively; conjugation is much less in evidence in the $a$-past tense. The auxiliary part of the $a$-past compound tense often takes an additional auxiliary, which 
is often se [now or already]. In addition, complements may conjugate, often with an aspect, as in the following example: Wayesezojika achezukele emgwaqeni obheka kwakhe [...] [He was now going to turn into the road leading to his place [...]] (Sibiya 2002:3).

The compound tenses are the preferred tenses to express durative events or states, location, copulatives, and so forth, here is an example expressing a state in the past (expressing a state, locative, etc., in the past is in fact only possible in one of the compound tenses): Wayezimisele uLethiwe ngokuthi ngeke ayithi vu kuShumi le ndaba. [Lethiwe was determined that she would not say a word to Shumi about this matter] (Sibiya 2002:6).

The $a$-past compound tense does of course serve to express a remote past (over and above its capacity to narrate recent events), for example (from Sibiya 2002): Kwakukuso kanye lesi sibhedlela, eminyakeni eyishumi edlule [...] [It was at this very hospital, ten years ago [...]] (Sibiya 2002:4)

The a-past compound tense is a common occurrence in narrative texts; the same cannot be said of the past compound tense, which is dealt with next.

\section{The past compound tense}

Posthumus (2008:77) names the most basic form of this tense the 'relative tense with reference time shortly before coding time and event time coinciding with reference time'. Logically it refers to a recent past, but occasionally it does appear in the same time context as that of the $a$-past compound tense, as the following example shows: 'Ngempela Thuli?' kubuza u-Alex engakukholwa lokhu akuzwayo. Inhliziyo yayibhakuza sengathi izophuma ngomlomo. Wayengaqondi kahle ukuthi wayejabule kakhulu yini noma wayenokuzisola ngokuchitha isikhathi esingaka ibe imthanda intombi. ['Really Thuli?' asks Alex not believing what he is hearing. His heart pounded as if it would come out of his mouth. He did not understand fully whether he was happy or whether he blamed himself for wasting so much time whilst the girl was in love with him.] (Makhambeni 2006:80).

Logically, the clause ibe imthanda which is in the compound past tense, seems to refer to a time that precedes and overlaps with the other events, which are in the a-past compound tense, a tense traditionally accepted as preceding events in the past compound tense.

\section{Explanation:}

$\begin{array}{lllll}\text { Ibe (auxiliary verb) } & \text { imthanda (main verb) } \\ \text { I } & \text { be } & i & m & \text { thanda } \\ \text { SM CL 9 } & \text { AUX } & \text { SM CL 9 } & \text { OBJ M CL 1a } & \text { V STEM } \\ \text { She } & \text { be } & \text { she } & \text { him } & \text { love }\end{array}$

She loved him.

It was illustrated earlier that the $a$-past tense and the $a$-past compound tense may occur in the same context. The same is true of the past compound; it occurs in the same context as the a-past tense: Lagqagqamuka ihhashi. Wasondela umfula. Lwakhula uvalo kuSishebo. Wajuluka. Ukuba ubengabambile isikhuni ngalesi esinye isandla, ubezowesula umjuluko. [The horse reared up. The river approached. (= The river came closer and closer.) Sishebo's fear grew. He broke out in a sweat. If he had not been holding a torch in the other hand he would have wiped the sweat off] (Makhambeni 2006:14).

The first four verbs are in the $a$-past tense (its 'dramatic' nature well-illustrated here), whilst the rest are in the past compound tense. The past compound tense exhibits the richness of conjugation, equal to that of the a-past compound, but its occurrence in narrative texts is limited.

\section{The present compound tense}

IsiZulu grammarians do not discuss a present compound tense. This is perhaps because it does not seem to differ grammatically from the past compound; it can however be recognised on logical semantic grounds and from the fact that the auxiliary phrase and the complement do not contract, as is the norm with past forms of compound tenses. See the following example: 'Wena Sivalo uthi le ngane ayifane kanjani namantombazane ibe ingumfana yona?' [...] [I say Sivalo in what way do you say (= mean) this child does not resemble the girls as it is a boy? [...]] Paraphrase: [Sivalo, how can you say this child is not the same as the girls; it is in fact a boy?] (Makhambeni 2006:3)

Except for the fact that the complement is an identifying copulative (ingumfana - [it is a boy]), the word group has the same basic structure as other compound tenses. This compound tense occurs much less frequently than other compound tenses.

\section{Compound future tenses}

As stated earlier, Posthumus (2008) does not recognise an absolute future tense, but he does recognise (eight variants of) the definite and indefinite future relative tenses. As stated before, with regard to the future tense speakers and writers have the need to refer to future events (for communicative reasons); for this reason future compound tenses are recognised here. A future compound tense contains a future morpheme $(z o$ or $y o)$ in the auxiliary phrase; examples where a 'future' aspect occurs in the complement will not be recognised as 'the future', since occurrences of semantic variations such as the 'future' in the complement cannot be regarded as intrinsic future tense values.

Example of definite future compound tense: Ngizobe ngingekho kusasa. [I will not be here tomorrow.]

Example of indefinite future compound tense: Bayobe bezidonsela amanzi ngomsele. [They will be causing trouble for themselves.]

\section{Explanation:}

$\mathrm{Ba}$ yo be be $\mathrm{zi}$ donsela

SMCL 2 FUT AUX SMCL 2 SIT MOOD OBJM(refl) V STEM

They will be they themselves draw for

(They will be drawing (a stream of water to themselves). 
TABLE 2: The tenses of isizulu.

\begin{tabular}{|c|c|c|c|c|c|}
\hline Tenses & A-past & Past & Present & Definite future & Indefinite future \\
\hline Basic & $\begin{array}{l}\text { Ngafika. } \\
\text { [I arrived.] }\end{array}$ & $\begin{array}{l}\text { Ngifike izolo. } \\
\text { [I arrived yesterday.] } \\
\text { (Ngifikile. [I have arrived.] } \\
\text { (confirmative aspect)) }\end{array}$ & $\begin{array}{l}\text { Ngifika manje. [I am coming } \\
\text { now.] } \\
\text { (Ngiyafika. [I am coming.] } \\
\text { (emphatic aspect) }\end{array}$ & $\begin{array}{l}\text { Ngizofika. } \\
\text { [I will arrive.] }\end{array}$ & $\begin{array}{l}\text { Ngiyofika. } \\
\text { [I will arrive.] }\end{array}$ \\
\hline Compound & $\begin{array}{l}\text { Ngangifika. } \\
\text { [I arrived.] }\end{array}$ & $\begin{array}{l}\text { Bengifika. [I arrived/was } \\
\text { arriving.] }\end{array}$ & $\begin{array}{l}\text { *ongabe uyenza } \\
\text { [*you can be doing] }\end{array}$ & $\begin{array}{l}\text { Ngizobe ngifika. [I will be } \\
\text { arriving.] }\end{array}$ & $\begin{array}{l}\text { Ngiyobe ngifika. [I will } \\
\text { be arriving.] }\end{array}$ \\
\hline
\end{tabular}

*, This clause is part of a sentence in Sibiya (2002:36) that reads as follows: 'Into ongabe uyenza nje myeni wami ngukucabanga uhlobo Iwemoto esizoyithenga [...]' [What you can be doing my husband is to think of the kind of car we will buy [...]].

This example occurs with the potential aspect -nga- (can or may).

TABLE 3: Tenses and event types.

\begin{tabular}{lll}
\hline Tense & Event type & Unique use or meaning \\
\hline A-past & Activity & Presents activity as seminal \\
Past & State, activity & Presents perfectivity. Long form confirms or emphasises \\
Present & Activity, state & Habitual, momentary, universal events. Long form confirms or emphasises \\
Definite future & Activity & Imminence \\
Indefinite future & Activity & Distant action \\
Compound A-past & Activity, state & Presents activity or state as seminal. Presents activity or state as continuous \\
Compound past & Activity, state & Presents activity or state as continuous \\
Compound present & Activity, state & Presents activity or state as continuous \\
Compound definite future & Activity, state & Presents activity or state as immanent. Presents activity or state as continuous \\
Compound indefinite future & Activity, state & Presents activity or state as distant. Presents activity or state as continuous \\
\hline
\end{tabular}

\section{Conclusion}

Based on the arguments and examples set out above, a distinction between so-called absolute and relative tenses is not reasonable. However, it is clear that isiZulu avails itself of radical, simple or basic tenses - the description 'basic' is preferred - and of compound tenses. Furthermore, for communicative purposes a future tense needs to be recognised. It has been shown that basic and compound tenses may occur in the same time reference and even in the same linguistic unit (the sentence). Why the need for two types of tenses (basic and compound)? The answer is simple: to provide for nuanced expression. Whilst the basic tenses provide the semantic values as discussed, the compound tenses add the value [+continuous] whilst they conjugate more freely than the basic tenses by adding aspects. See the summary of the tenses according to the analyses provided in the foregoing discussion (Table 2).

The four past tenses is an indication of the fact that these tenses are needed for specific purposes. Since I am not aware of a detailed study on the specific event types that characterise isiZulu tenses, the details presented in Table 3 are preliminary. I will also take the liberty to work with only two types of events, namely state and activity. In the third column an indication is given of the tense's unique use(s), as seen in the analyses of the examples.

Narrative texts have revealed features of tenses in isiZulu that have been overlooked by some grammarians. There should be no doubt that the use of tenses in narrative texts demand a revision of the classification and grammatical description of tenses in isiZulu.

\section{Acknowledgments Competing interests}

The author declares that he has no financial or personal relationship(s) that may have inappropriately influenced him in writing this article.

\section{References}

Comrie, B., 1985, Tense, Cambridge University Press, Cambridge. http://dx.doi. org/10.1017/СBO9781139165815

De Clerq, J., 1961, 'Verledetyd, subjunktief en konsekutief in Zulu', in J. Breed et al., (eds.), Feesbundel vir Prof. Dr. Jan Antonie Engelbrecht, Afrikaanse Pers Beperk, Johannesburg. PMid:13924565

Doke, C.M., [1927] 1988, Textbook of Zulu grammar, 6th edn., Maskew Miller Longman, Cape Town. PMid:3178217

Grandison A., McGinley D., Shearer T., Knight, L., Ford, C., 1990, s.v. 'absolute', in The Collins paperback English dictionary, new edn., William Collins Sons, Glasgow, p. 3.

Kashina, K., 2005, The Silozi clause. A study of the structure and distribution of its constituents, Lincom $\mathrm{GmbH}$, München.

Lehmann, C., 2002, Thoughts on grammaticalization, Arbeitspapiere des Seminars für Sprachwissenschaft der Universität Erfurt, Seminar für Sprachwissenschaft, Philosophische Fakultät, Universität Erfurt, Erfurt, viewed 23 October 2012 from http://www.db-thueringen.de/servlets/DerivateServlet/Derivate-2058/ ASSidUE09.pdf

Makhambeni, N., 2006, Sidla ingqatho nefutho, Afritude, Groenkloof

Posthumus, L.C., 1982, 'A review of the so-called -be/-ba past tenses of Zulu', South African Journal of African Languages 2(2), 94-108.

Posthumus, L.C., 1984, 'Tyd en tempus met besondere verwysing na Zulu', Linguistevereniging van Suider-Afrika Kongresreferate 2, 507-520.

Posthumus, L.C., 1988, 'Basis for tense analysis in the African languages', South African Journal of African Languages 8(4), 139-143.

Posthumus, L.C., 1990, 'Time reference in Zulu', South African Journal of African Languages 10(1), 22-28.

Posthumus, L.C., 2001, 'The distinction between absolute and relative tenses with reference to Zulu', Hermeneus 3, 279-304.

Posthumus, L.C., 2006, 'The spectrum of the-be relative tenses of Zulu', South African Association for Language Teaching 40(1), 100-116.

Posthumus, L.C., 2008, 'Naming the so-called continuous past tenses of the southeastern Bantu languages with particular reference to Zulu', South African Journa of African Languages 28(1), 69-79.

Poulos, G. \& Msimang, C.T., 1998, A linguistic analysis of Zulu, Via Afrika, Cape Town.

Sibiya, N.G., 2002, Kuxolelwa abanjani?, Shuter \& Shooter, Pietermaritzburg.

Sibiya, N.G., 2008, Bengithi lizokuna, Nutrend, Pietermaritzburg. PMid:18023238

Sithole, N.V., 2003, Event structure in Zulu, D. Litt. thesis, University of Stellenbosch.

Smith, C.S., 2008, 'Time with and without tense', in J. Guéron \& J. Lecarme (eds.), Time and modality, pp. 231, 246, Springer, Paris.

Taljaard, P.C. \& Bosch, S.E., 1998, 2nd edn., Handbook of isizulu, Van Schaik, Pretoria. Thompson, G., 2004, Introduction to functional grammar, Arnold, London.

Van Eeden, B.I.C., 1956, Zoeloe-grammatika, Die Universiteitsuitgewers en Boekhandelaars, Stellenbosch. 